\title{
OPTIMIZATION OF IN VITRO ORGANOGENESIS IN PASSION FRUIT (PASSIFLORA EDULIS F. FLAVICARPA)
}

\author{
Flavio Trevisan ${ }^{1}$; Beatriz Madalena Januzzi Mendes ${ }^{2 *}$ \\ ${ }^{1}$ USP/ESALQ - Programa de Pós-Graduação em Fisiologia e Bioquímica de Plantas, C.P. 9 - 13418-900 - \\ Piracicaba, SP - Brasil. \\ ${ }^{2}$ USP/CENA - Lab. de Biotecnologia Vegetal, C.P. 96 - 13400-970 - Av. Centenário 303, Piracicaba, SP - Brasil. \\ *Corresponding author <bmendes@cena.usp.br>
}

\begin{abstract}
In vitro organogenesis of passion fruit was studied by the induction of adventitious buds from leaf discs in culture media supplemented with benzyladenine (BAP) or thidiazuron (TDZ). To minimize adverse effects of ethylene accumulation on shoot development, silver nitrate $\left(\mathrm{AgNO}_{3}\right)$ was added to the induction media. Both BAP $\left(0 ; 2.2 ; 4.4 ; 6.6 \mu \mathrm{mol} \mathrm{L}^{-1}\right)$ and TDZ $\left(0 ; 1.1 ; 2.2 ; 3.4 \mu \mathrm{mol} \mathrm{L}^{-1}\right)$ were effective in promoting shoot development. Although no significant differences were detected using $\operatorname{AgNO}_{3}\left(23.5 \mu \mathrm{mol} \mathrm{L}^{-1}\right)$, buds grown in $\mathrm{AgNO}_{3}$-supplemented media were more vigorous. The number of explants with buds obtained using TDZ and $\mathrm{AgNO}_{3}$-supplemented media (5.6) were higher than those obtained using $\mathrm{BAP}$ and $\mathrm{AgNO}_{3}$ (3.0). MSM + giberrellic acid $\left(\mathrm{GA}_{3}\right), \mathrm{MSM}+$ coconut water, and $1 / 2 \mathrm{MSM}$ culture media were tested for shoot bud elongation, incubated in flasks covered with either non-vented or vented lids. Best results were obtained by culturing buds in MSM + coconut water media in flasks covered with vented lids. Plantlets transferred to MSM + indol butyric acid (IBA) media rooted in a 30-day period. Passion fruit organogenesis was enhanced by using TDZ and $\mathrm{AgNO}_{3}$ for bud induction. Transferring the buds to MSM + coconut water media and incubating in flasks with vented lids favored shoot elongation and plantlet development.
\end{abstract}

Key words: ethylene, silver nitrate, thidiazuron, tissue culture

\section{OTIMIZAÇÃO DA ORGANOGÊNESE IN VITRO DE MARACUJAZEIRO (PASSIFLORA EDULIS F. FLAVICARPA)}

\begin{abstract}
RESUMO: A organogênese in vitro de maracujá foi estudada pela indução de gemas adventícias em discos de folha cultivados em meio de cultura suplementado com benziladenina (BAP) ou thidiazuron (TDZ). Nitrato de prata $\left(\mathrm{AgNO}_{3}\right)$ foi adicionado ao meio de cultura de indução de gemas adventícias para minimizar o efeito do acúmulo de etileno no desenvolvimento dos brotos. Tanto BAP $\left(0 ; 2,2 ; 4,4 ; 6,6 \mu \mathrm{mol} \mathrm{L}^{-1}\right)$ como TDZ ( 0 ; 1,$\left.1 ; 2,2 ; 3,4 \mu \mathrm{mol} \mathrm{L}^{-1}\right)$ foram eficientes em promover o desenvolvimento de brotos. Embora diferenças significativas no uso de $\mathrm{AgNO}_{3}\left(23,5 \mu \mathrm{mol} \mathrm{L}^{-1}\right)$ não tenham sido detectadas, gemas adventícias desenvolvidas em meio de cultura suplementado com $\mathrm{AgNO}_{3}$ eram mais vigorosas. $\mathrm{O}$ número de explantes com gemas obtidos no meio de cultura suplementado com TDZ e $\mathrm{AgNO}_{3}(5,6)$ foi maior do que aquele obtido com BAP e $\mathrm{AgNO}_{3}(3,0)$. Os meios de cultura MSM + ácido giberélico $\left(\mathrm{GA}_{3}\right), \mathrm{MSM}+$ água de coco ou $1 \frac{1}{2} \mathrm{MSM}$ foram utilizados para o alongamento dos brotos, os quais foram incubados em frascos com tampas ventiladas ou tampas normais. Os melhores resultados foram obtidos cultivando-se as gemas adventícias no meio de cultura MSM + água de coco em frascos com tampas ventiladas. As plântulas transferidas para meio de cultura MSM + ácido indol butírico enraizaram num período de 30 dias. A organogênese in vitro de maracujazeiro foi otimizada utilizando-se $\mathrm{TDZ}+\mathrm{AgNO}_{3}$ para a indução de gemas adventícias. A transferência das gemas para meio de cultura MSM + água de coco e a incubação em frascos com tampas ventiladas favoreceu o alongamento e o desenvolvimento de plântulas.

Palavras-chave: cultura de tecidos, etileno, nitrato de prata, thidiazuron
\end{abstract}

\section{INTRODUCTION}

In vitro regeneration in passion fruit (Passiflora edulis Sims. f. flavicarpa Deg.) has been obtained from shoot apices or nodal segments cultivation (Drew, 1991; Faria \& Segura, 1997a; Monteiro et al., 2000; Reis et al., 2003) or from adventitious buds developed from leaf discs (Dornelas \& Vieira, 1994; Appezzato-da-Glória et al., 1999), hypocotyl (Faria \& Segura, 1997b), or intern- odal segments (Biasi et al., 2000). Optimized protocols have been established mainly by using different combinations of plant growth regulators, such as BAP and IBA (Kawata et al., 1995), BAP and NAA (Dornelas \& Vieira, 1994), BAP and IAA (Faria \& Segura, 1997b), and different salt solutions (Faria \& Segura, 1997b; Monteiro et al., 2000).

In vitro morphogenesis depends not only on chemicals present in the nutrient medium but also on at- 
mosphere composition in the culture vessel (Lai et al., 1998; Zobayed et al., 1999). Ethylene accumulation in tissue culture vessel is a consequence of the method (Biddington, 1992; Zobayed et al., 1999). Cultivation conditions, associated with the fact that passion fruit produces ethylene at high rates (Ludford, 1995), indicates that the possibility of ethylene accumulation in tissue culture flasks needs to be taken into account. Culture media supplementation with inhibitors blocking ethylene production or action, enhance morphogenesis in several plant species (Pua \& Chi, 1993; Pestana et al., 1999; Mohiuddin et al., 1997).

Faria \& Segura (1997b) demonstrated that the addition of silver thiosulfate (STS) to culture media significantly increased the differentiation and development of adventitious shoots in passion fruit. The use of ventilated culture vessels has also been mentioned as an alternative to modify vessel atmosphere and improve gas exchange (Zobayed et al., 1999) in in vitro culture.

This work studied the effects of culture media supplemented with BAP or TDZ growth regulators on in vitro passion fruit organogenesis from leaf discs. To minimize the effects of ethylene accumulation in culture flasks, both the supplementation of induction media with $\mathrm{AgNO}_{3}$ and the growth of buds in flasks covered with vented lids were studied.

\section{MATERIAL AND METHODS}

\section{Plant material}

Seeds (Passiflora edulis f. flavicarpa) were collected from ripe passion fruits, soaked for $15 \mathrm{~min}$ in distilled water $\left(45^{\circ} \mathrm{C}\right)$, surface-sterilized in $25 \%$, commercial bleach solution (2.5\% sodium hypochloride) for 15 $\mathrm{min}$, followed by three rinses in sterile, distilled water. Seeds were germinated aseptically in culture vessels containing $1 / 2$ MS salts and vitamins (Murashige \& Skoog, $1962)$, sucrose $(2.5 \%)$, and agar $(0.8 \%$, Sigma), $\mathrm{pH} 5.8$, incubated at $27^{\circ} \mathrm{C}$ and 16 -h photoperiod. Explants consisted of 6-mm leaf discs isolated from young leaves from 60-day-old seedlings. Explants were cultivated with abaxial surface up.

\section{Bud induction}

Explants were cultured on MS medium supplemented with one of the following growth regulators: 0 , $2.2,4.4,6.6 \mu \mathrm{mol} \mathrm{L}{ }^{-1}$ BAP or $0,1.1,2.2,3.4 \mu \mathrm{mol} \mathrm{L}{ }^{-1}$ $\mathrm{TDZ}$, with or without $23.5 \mu \mathrm{mol} \mathrm{L} \mathrm{AgNO}_{3}$. Trials were set up in completely randomized experimental design (n $=5)$, each replication consisting of one Petri dish $(100 \times$ $15 \mathrm{~mm}$ ) with eight leaf discs. Cultures were incubated at $27^{\circ} \mathrm{C}$, in the dark. All media were supplemented with $3 \%$ sucrose, $0.8 \%$ agar (Sigma) and $\mathrm{pH}$ was adjusted to 5.8 before autoclaving $\left(121^{\circ} \mathrm{C}, 20 \mathrm{~min}\right) . \mathrm{AgNO}_{3}$ was filtersterilized and added to autoclaved medium. After four weeks, explants were scored under stereo microscope for the number of explants with shoots. To determine the optimal cytokinin for bud induction, results from BAP experiment were compared with those from TDZ experiment. Statistical analysis was performed on $(x+0.5)^{1 / 2}$ transformed data. Mean number of responsive explants were compared by ANOVA. Tukey's multiple range test $(\alpha=0.01)$ was used for means comparison.

\section{Shoot elongation and rooting}

Shoots obtained from leaf discs cultured on MS medium supplemented with $1.1 \mu \mathrm{mol} \mathrm{L^{-1 }} \mathrm{TDZ}+23.5$ $\mu \mathrm{mol} \mathrm{L} \mathrm{AgNO}_{3}$ were transferred for elongation to Magenta GA7 boxes (Sigma) containing one of the following culture media: MSM (Monteiro et al., 2000) supplemented with $2.6 \mu \mathrm{mol} \mathrm{L}{ }^{-1} \mathrm{GA}_{3}$; MSM supplemented with coconut water $(10 \%)$; or $1 / 2$ MSM salts, in a completely randomized experimental design $(n=5)$, each replication consisting of one Magenta GA7 box with five explants. Flasks were capped with normal or vented lids (Sigma). After 45 days, plantlets with four to five leaves were transferred to MSM medium supplemented with $4.9 \mu \mathrm{mol}$ $\mathrm{L}^{-1}$ IBA for rooting, incubated at 16 -h photoperiod, $27^{\circ} \mathrm{C}$. Subcultures were set up at 15 days intervals. Plants were transplanted to pots with sterile substrate (Rendmax TM) and covered with transparent plastic bag for acclimatization. The plastic bags were gradually removed until complete acclimatization to the ambient humidity (15-20 days).

\section{RESULTS AND DISCUSSION}

After four weeks of culture on induction medium, direct organogenesis was observed with multiple shoot formations along the leaf disc cut edge. Tables 1 and 2 show results obtained with culture media supplemented with various concentrations of BAP or TDZ, with or with-

Table 1 - Shoot bud formation in passion fruit (P. edulis) leaf discs treated with different BAP concentrations, with or without $\mathrm{AgNO}_{3}$.

\begin{tabular}{llll}
\hline \multirow{2}{*}{ BAP } & \multicolumn{3}{c}{ Number of explants with buds $(\%) \mathrm{AgNO}_{3}$} \\
\cline { 2 - 4 } & \multicolumn{1}{c}{0.0} & \multicolumn{1}{c}{23.5} & Mean \\
\hline-0.0 & $0.0(0.0)$ & $0.0(0.0)$ & $0.0(0.0) \mathrm{a}$ \\
2.2 & $2.2(27.5)$ & $2.0(25.0)$ & $2.1(26.5) \mathrm{b}$ \\
4.4 & $3.8(47.5)$ & $4.6(57.5)$ & $4.2(52.5) \mathrm{c}$ \\
6.6 & $4.8(60.0)$ & $5.2(65.0)$ & $6.0(75.0) \mathrm{c}$ \\
\hline Mean & $2.7(33.7) \mathrm{A}$ & $2.95(36.8) \mathrm{A}$ & \\
\hline
\end{tabular}

Each value represents the average (\%) of five replications, a total of 40 explants per treatment

Means followed by the same letter do not differ (Tukey's test, $\alpha=$ 0.01 ) (lower-case in column and upper-case in line). Original data were transformed using $(\mathrm{x}+0.5)^{1 / 2}$ 
Table 2 - Shoot bud formation in passion fruit (P. edulis) leaf discs treated with different TDZ concentrations, with or without $\mathrm{AgNO}_{3}$.

\begin{tabular}{|c|c|c|c|}
\hline \multirow{2}{*}{ TDZ } & \multicolumn{3}{|c|}{ Number of explants with buds (\%) $\mathrm{AgNO}_{3}$} \\
\hline & 0.0 & 23.5 & Mean \\
\hline \multicolumn{4}{|c|}{ nol L $\mathrm{L}^{-1} \ldots \ldots \ldots$} \\
\hline 0.0 & $0.0(0.0)$ & $0.0(0.0)$ & $0.0(0.0)$ a \\
\hline 1.1 & $5.8(72.5)$ & $6.6(82.5)$ & $6.2(77.5) b$ \\
\hline 2.2 & $5.0(62.5)$ & $5.4(67.5)$ & $5.2(65.0) b$ \\
\hline 3.4 & $3.2(40.6)$ & $5.8(72.5)$ & $4.5(56.2) \mathrm{b}$ \\
\hline Mean & $3.5(43.8) \mathrm{A}$ & $4.45(55.6$ & \\
\hline
\end{tabular}

Each value represents the average (\%) of five replications 40 explants per treatment

Means followed by the same letter do not differ (Tukey's test, $\alpha=$ 0.01 ) (lower-case in column and upper-case in line). Original data were transformed using $(\mathrm{x}+0.5)^{1 / 2}$.

out $\mathrm{AgNO}_{3}$. Organogenesis did not occur in the absence of growth regulators, and both BAP and TDZ were effective in promoting adventitious buds development. No significant differences in the proportion of responsive explants was detected relatively to the use of $\mathrm{AgNO}_{3}$.

Adventitious shoots developed on media supplemented with $\mathrm{AgNO}_{3}$ were more vigorous than those developed in the absence of $\mathrm{AgNO}_{3}$ (Figures 1a-d). Therefore, concentrations of $4.4 \mu \mathrm{mol} \mathrm{L}^{-1} \mathrm{BAP}$ and $1.1 \mu \mathrm{mol}$ $\mathrm{L}^{-1} \mathrm{TDZ}$ were chosen for comparing the effectiveness of growth regulators in adventitious bud development.

The number of explants with buds was higher in media supplemented with $\mathrm{TDZ}$ and $\mathrm{AgNO}_{3}(70.0 \%)$ (Table 3). As previously indicated by Faria \& Segura (1997b), the number of buds per explant was difficult to quantify because buds usually appear in compact clusters. On the other hand it was possible to visualize that induction medium supplemented with TDZ resulted in a high frequency of buds per explant $(60.0 \%)$, that is, TDZ + $\mathrm{AgNO}_{3}$ induced high shoot quality, high proportion of explants with a high number of buds per explants.

In vitro organogenesis of passion fruit has been reported by culturing explants in media supplemented with BAP or BAP + NAA (Dornelas \& Vieira, 1994), or BAP + coconut water (Hall et al., 2000). Although TDZ has been reported as effective growth regulator for adventitious shoot induction in several crops (Malik \& Saxena, 1992; Zhang et al., 2001; Fratini \& Ruiz, 2002), its effect has not yet been tested in passion fruit in vitro culture.

Ethylene action or biosynthesis inhibitors protect in vitro-cultured tissues from accumulated ethylene toxic effect (Magdalita et al., 1997) and stimulate their growth and development (Mohiuddin et al., 1997). The use of growth regulators in combination with ethylene inhibitors to improve morphogenesis has been reported for pa-
Table 3 - Shoot bud formation in passion fruit (P. edulis) leaf discs treated with BAP or TDZ, with or without $\mathrm{AgNO}_{3}$.

\begin{tabular}{lccc}
\hline \multirow{2}{*}{$\begin{array}{l}\text { Growth } \\
\text { regulator }\end{array}$} & \multicolumn{3}{c}{ Number of explants with buds (\%) $\mathrm{AgNO}_{3}$} \\
\cline { 2 - 4 } & 0.0 & 23.5 & Mean \\
\hline $\begin{array}{l}\text { Control } \\
\text { BAP }\end{array}$ & $0.0(0.0)$ & $0.0(0.0)$ & $0.0(0.0) \mathrm{a}$ \\
$\left(4.4 \mu \mathrm{mol} \mathrm{L}^{-1}\right)$ & $0.8(10.0)$ & $3.0(37.5)$ & $1.9(23.7) \mathrm{b}$ \\
$\begin{array}{l}\text { TDZ } \\
\left(1.1 \mu \mathrm{mol} \mathrm{L}^{-1}\right)\end{array}$ & $4.0(50.0)$ & $5.6(70.0)$ & $4.8(60.0) \mathrm{c}$ \\
\hline Mean & $1.6(20.0) \mathrm{A}$ & $2.8(35.0) \mathrm{B}$ \\
\hline
\end{tabular}

Each value represents the average (\%) of seven replications, 56 explants per treatment

Means followed by the same letter do not differ (Tukey's test, $\alpha=$ 0.01 ) (lower-case in column and upper-case in line). Original data were transformed using $(x+0.5)^{1 / 2}$.

Table 4 - Efficiency of shoot bud elongation in passion fruit (P. edulis) using different culture media, with or without vented lids.

\begin{tabular}{lccc}
\hline \multirow{2}{*}{ Culture Media } & \multicolumn{3}{c}{ Number of elongated buds/total buds } \\
\cline { 2 - 4 } & $\begin{array}{c}\text { Vented } \\
\text { lids }\end{array}$ & $\begin{array}{c}\text { Non-vented } \\
\text { lids }\end{array}$ & Mean \\
\hline MSM + GA 3 & $1.2 / 5$ & $0.60 / 5$ & $0.9 / 5 \mathrm{ab}$ \\
$\begin{array}{l}\text { MSM + } \\
\text { coconut water }\end{array}$ & $2.8 / 5$ & $0.75 / 5$ & $1,7 / 5 \mathrm{a}$ \\
$1 / 2 \mathrm{MSM}$ & $0.5 / 5$ & $0.25 / 5$ & $0.37 / 5 \mathrm{~b}$ \\
\hline Mean & $1.5 / 5 \mathrm{~A}$ & $0.53 / 5 \mathrm{~B}$ & \\
\hline
\end{tabular}

Values represent the average (\%) of five replications, 25 explants per treatment.

Means followed by the same letter do not differ (Tukey's test, $\alpha=$ 0.01 ) (lower-case in column and upper-case in line). Original data were transformed using $(\mathrm{x}+0.5)^{1 / 2}$.

paya (Lai et al., 1998), cauliflower (Zobayed et al., 1999) and cucumber (Mohiuddin et al., 1997). For passion fruit, Faria \& Segura (1997b) found an increase in the frequency of buds by the use of STS in leaf disc and hypocotyl tissue culture.

Besides chemical methods, an alternative to manipulate gaseous conditions in the vessel headspace is improving flask ventilation to allow efficient gas exchange (Lai et al., 1998). Passion fruit shoots derived from explants cultivated in culture media in the presence of $\mathrm{TDZ}+\mathrm{AgNO}_{3}$ developed into whole plants upon transferring to elongation media. Table 4 showed that the use of vented lids in combination with the supplementation of culture media with coconut water increased the number of elongated shoots (Figure 1e). The use of coconut water in passion fruit tissue culture increases both the percentage of explants with shoots (Dornelas \& Vieira, 1994; Hall et al., 2000) and the shoot height (Hall et al., 2000), resulting in shoots with a better quality and appearance. 

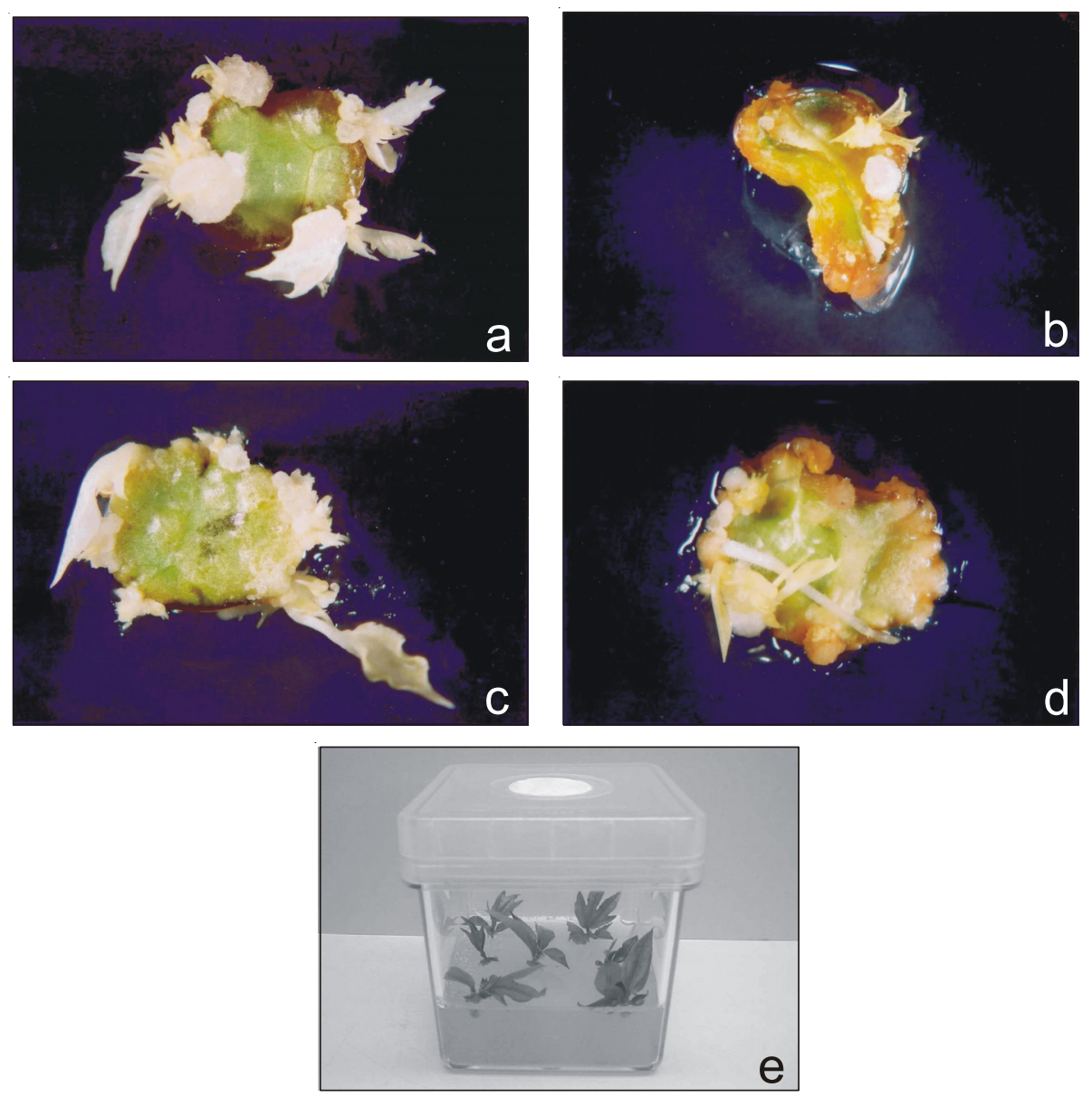

Figure 1 - In vitro organogenesis in passion fruit (P. edulis). Multiple shoot buds developed from leaf discs cultured in medium supplemented with $\mathrm{TDZ}+\mathrm{AgNO}_{3}(\mathrm{a}), \mathrm{TDZ}$ without $\mathrm{AgNO}_{3}(\mathrm{~b}), \mathrm{BAP}+\mathrm{AgNO}_{3}$ (c), BAP without $\mathrm{AgNO}_{3}(\mathrm{~d})$; plantlets obtained in elongation medium MSM + coconut water, in culture vessel with vented lids (e).

The type of sealing material used in in vitro culture is known to influence plant growth and development (Buddendorf-Joosten \& Woltering, 1994) and the use of vented lids exerts positive effects on papaya micropropagation (Lai et al., 1998) and cauliflower seedlings growth (Zobayed et al., 1999). The positive effects of flasks gaseous atmosphere manipulation is mainly due to ethylene and $\mathrm{CO}_{2}$ exchange with the open air.

Two to three-cm long passion fruit plantlets rooted 30 days after being transferred to culture medium supplemented with IBA. The higher number of explants with shoots obtained in the presence of $\mathrm{AgNO}_{3}$ and the higher efficiency in shoot elongation when vented lids were used indicated that, as suggested by Faria \& Segura (1977b), the morphogenic capacity of $P$. edulis was limited by the ethylene accumulated in the culture flask.

Protocols on the use of shoot induction medium with $\mathrm{TDZ}+\mathrm{AgNO}_{3}$, as well as the supplementation of elongation medium with coconut water in combination with the use of vented lids for passion fruit tissue culture, presented herein can be applied to breeding programs, particularly to facilitate transgenic passion fruit plants production.

\section{ACKNOWLEDGEMENTS}

To FAPESP for financial support and scholarship to first author and CNPq for a research fellowship to the second author.

\section{REFERENCES}

APPEZZATO-DA-GLÓRIA, B.; VIEIRA, M.L.C.; DORNELAS, M.C. Anatomical studies of in vitro organogenesis induced in leaf-derived explants of passionfruit. Pesquisa Agropecuária Brasileira, v.34, p.2007-2013, 1999.

BIASI, L.A.; FALCO, M.C.; RODRIGUEZ, A.P.M.; MENDES, B.M.J. Organogenesis from internodal segments of yellow passionfruit (Passiflora edulis f. flavicarpa). Scientia Agricola, v.57, p.661-665, 2000.

BIDDINGTON, N.L. The influence of ethylene in plant tissue culture. Plant Growth Regulation, v.11, p.173-187, 1992.

BUDDENDORF-JOOSTEN, J.M.C.; WOLTERING, E.J. Components of the gaseous environment and their affects on plant growth and development in vitro. Plant Growth Regulation, v.15, p.1-16, 1994.

DORNELAS, M.C.; VIEIRA, M.L.C. Tissue culture studies on species of Passiflora. Plant Cell, Tissue and Organ Culture, v.36, p.211-217, 1994.

DREW, R.A. In vitro culture of adult and juvenile bud explants of Passiflora species. Plant Cell, Tissue and Organ Culture, v.26, p.23-27, 1991.

FARIA, J.L.C.; SEGURA, J. Micropropagation of yellow Passionfruit by axillary bud proliferation. HortScience, v.32, p.1276-1277, 1997a. 
FARIA, J.L.C.; SEGURA, J. In vitro control of adventitious bud differentiation by inorganic medium components and silver thiosulfate in explants of Passiflora edulis f. flavicarpa. In Vitro Cellular \& Developmental Biology-Plant, v.33, p.209-212, 1997 b.

FRATINI, R.; RUIZ, M.L. Comparative study of different cytokinins in the induction of morphogenesis in lentil (Lens culinaris Medik.). In Vitro Cellular \& Developmental Biology-Plant, v.38, p.46-51, 2002.

HALL, R.M.; DREW, R.A.; HIGGINS, C.M.; DIETZGEN, R.G. Efficient organogenesis of an Australian passionfruit hybrid (Passiflora edulis $\mathrm{x}$ Passiflora edulis var. flavicarpa) suitable for gene delivery. Australian Journal of Botany, v.48, p.673-680, 2000.

KAWATA, K.; USHIDA, C.; KAWAI, F.; KANAMORI, M.; KURIYAMA, A. Micropropagation of passionfruit from subcultured multiple shoot primordia. Journal of Plant Physiology, v.147, p.281-284, 1995.

LAI, C.C.; YU, T.A.; YEH, S.D.; YANG, J.S. Enhancement of in vitro growth of papaya multishoots by aeration. Plant Cell, Tissue and Organ Culture, v.53, p.221-225, 1998.

LUDFORD, P.M. Postharvest hormone changes in vegetables and fruit. In: DAVIES, P.J. (Ed.) Plant hormones. Dordrecht: Kluwer Academic Publishers, 1995. p.725-750.

MAGDALITA, P.M.; GODWIN, I.D.; DREW, R.A.; ADKINS, S.W. Effect of ethylene and culture environment on development of papaya nodal cultures. Plant Cell, Tissue and Organ Culture, v.49, p.93-100, 1997.

MALIK, K.A.; SAXENA, P.K. Thidiazuron induces high-frequency shoot regeneration in intact seedlings of pea (Pisum sativum), chickpea (Cicer arietinum) and lentil (Lens culinaris). Australian Journal of Plant Physiology, v.19, p.731-740, 1992.

MOHIUDDIN, A.K.M.; CHOWDHURY, M.K.U.; ABDULLAH, Z.C.; NAPIS, S. Influence of silver nitrate (ethylene inhibitor) on cucumber in vitro shoot regeneration. Plant Cell, Tissue and Organ Culture, v.51, p.75-78, 1997.

MONTEIRO, A.C.B.A.; HIGASHI, E.N.; GONÇALVES, A.N.; RODRIGUEZ, A.P.M. A novel approach for the inorganic medium components for micropropagation of yellow passionfruit (Passiflora edulis Sims. f. flavicarpa Deg.). In Vitro Cellular \& Developmental Biology-Plant, v.36, p.527-531, 2000.
MURASHIGE, T.; SKOOG, F. A revised medium for rapid growth and bioassays with tobacco tissue cultures. Physiologia Plantarum, v.15, p.473-497, 1962.

PESTANA, M.C.; LACORTE, C.; FREITAS, V.G.; OLIVEIRA, D.E.; MANSUR, E. In vitro regeneration of peanut (Arachis hypogaea L.) through organogenesis: effect of culture temperature and silver nitrate. In Vitro Cellular \& Developmental Biology-Plant, v.35, p.214-216, 1999.

PUA, E.C.; CHI, G.L. De novo shoot morphogenesis and plant growth of mustard (Brassica juncea) in vitro in relation to ethylene. Physiologia Plantarum, v.88, p.467-474, 1993.

REIS, L.B.; PAIVA NETO, V.B.; TOLEDO PICOLI, E.A.; COSTA, M.G.C.; RÊGO, M.M.; CARVALHO, C.R.; FINGER, F.L.; OTONI, W.C. Axillary bud development of passionfruit as affected by ethylene precursor and inhibitors. In Vitro Cellular \& Developmental BiologyPlant, v.39, p.618-622, 2003.

ZHANG, C.L.; CHEN, D.F.; ELLIOTT, M.C.; SLATER, A. Thidiazuroninduced organogenesis and somatic embryogenesis in sugar beet (Beta vulgaris L.). In Vitro Cellular \& Developmental Biology-Plant, v.37, p.305-310, 2001.

ZOBAYED, S.M.A.; ARMSTRONG, J.; ARMSTRONG, W. Evaluation of a closed system, diffuse and humidity-induced convective through flow ventilation on the growth and physiology of cauliflower in vitro. Plant Cell, Tissue and Organ Culture, v.59, p.113-123, 1999.

Received February 03, 2005

Accepted June 03, 2005 